\title{
Beyond translation into chaos: exploring language movement in the French Caribbean
}

\author{
Catriona Cunningham \\ Queen's University Belfast
}

As Edwin Gentzler's latest book (2001) reveals, translation studies (as opposed to translating) is an area that is becoming increasingly relevant to both cultural and literary studies. Developing this point further, Sherry Simon states that, "Increasingly, translation and writing have become a particularly strong form of writing at a time when national cultures have themselves become diverse, inhabited by plurality"(Simon 1999: 72). Or indeed how "Symbolically, translation comes to be the very representation of the play of equivalence and difference in cultural interchange: translation permits communication without eliminating the grounds of specificity" (Simon 1992: 159). Therefore, particularly in postcolonial contexts, where the balance of power hinges on questions of language possession and linguistic insecurities, translation allows this power to be repositioned: it can establish a form of plurality by refusing to allow one language to dominate another. In recent works exploring the complex relationship between postcolonial environments and translation, ${ }^{1}$ these issues are examined in a worldwide context - writings from Quebec, North Africa, India constitute but a few examples. Yet, Simon also draws our attention to processes of translation that allow each language to maintain its own specific identity. In the French Caribbean, this becomes highly problematic because of the tensions between French - the official language - and Creole - the native spoken language. ${ }^{2}$ This article will explore the difficulties involved in establishing and maintaining this language specificity and will look at how, and if, French and Creole can 'translate' French Caribbean culture.

\section{Introduction}

Jeannie Suk (2001) has highlighted the difficulties of placing the French Caribbean islands of Martinique and Guadeloupe under the postcolonial banner, partly because of the problems involved in situating all former colonies in a similar context, but also because of the ambiguity of their ongoing colonial relationship with metropolitan France. As 'DOM', Départements d'Outre-Mer, since 1946, the islands are administratively and economically part of metropolitan France and continue to depend on their former colonial relationship. Since the 1970s, a number of intellectuals have been promoting a written form of the Creole language, which had hitherto been considered (and arguably continues to be seen) as inferior to French, thereby creating a diglossic situation. While there is some movement towards a validation of the Creole language - one can now take the 
'CAPES', the competitive national teaching exam, in Creole - the linguistic situation remains by and large unchanged. However, as we shall explore in this article, it is precisely the ambiguity and the tensions revolving around each language that render the question of translation in the French Caribbean so specific. In many postcolonial countries, the language of the other was imposed. In the French Caribbean there is an extremely important difference in that at the time of colonization, there was no language to impose. ${ }^{3}$ Instead, there was an urgent need for communication and the initial colonizers and colonized rapidly had to create a language, which involved the entire immigrant community. Over the centuries, with the arrival of - especially written - Standard French, and eventually widespread education, the roles for Creole and French within Martinican society have changed. Because of the relationship with Metropolitan France, French is considered to be the language of education and of social advancement while Creole is seen as the oral spontaneous language of intimacy and familiarity (Kremnitz 1983; March 1996). Nevertheless, the original formation of Creole by all the members of the community (also reflected in the language itself) complicates the rather straightforward notion of language 'imposition', and creates a unique set of linguistic tensions, thus assigning a new meaning to 'translation' in Martinique; one it does not necessarily have in other postcolonial situations.

\section{Language tensions in literature}

In Martinique, the tensions surrounding French are entrenched in the colonial past. Patrick Chamoiseau, ${ }^{4}$ a contemporary Martinican author and essayist, explores his ambivalent relationship with the French language in the 'autobiographical' novels of his childhood. For most members of the 1950s generation, Creole was the first language they encountered as children yet when they went to school, they were suddenly confronted with French, and expected to abandon their native language. In Une enfance créole II (1994) we read how Chamoiseau is first introduced to French in the form of an oral language in kindergarten (which is somewhat paradoxical, given that Creole is usually considered to be the oral language), but that experience holds none of the trauma or alienation that occurs later at school. He hears songs that make him forget the strangeness of the situation; he chants the letters of the alphabet with his fellow classmates, unaware that they constitute another language - that of the colonizer, the other - aware only that he loves the sound and unfamiliarity of this collective activity.

Man Salinière, un jour ou l'autre, accrochait de grosses lettres à son petit tableau. Dans un silence intrigué, elle articulait des sons chantants $A B C D$ [...] Chanter en ce temps-là se faisait avec l'âme. On devenait le chant, et le chant était sentiment vrai [...] On se donnait sans crainte, sans chercher à comprendre. [L]e négrillon se sentait envoûté, et il chantait, il chantait Aaaaa Bééé Céééé Dééééééé...(Chamoiseau, Une enfance créole II: 39-40) 
This extract reveals the gentleness and excitement of first hearing this new language - there is not a trace of the sense of alienation and marginalization that occurs later in the more formal context of primary school. Although the Creole language is not directly quoted, its presence is implicit and the reader is made to understand through the 'silence' of the children as they are first confronted with these strange new sounds and shapes that Chamoiseau is translating directly from Creole for us. The novelty of the French apparent in the "sans chercher à comprendre" is embraced by the children "sans crainte" through its sound. This experience is very different from later encounters in school, where those who do not understand French are ridiculed and are then ignored for being unable to follow, destined for the sugar cane fields. Initially, however, there is no fierce opposition set up between the two languages, simply the discovery of a new language (French) through sound and rhythm, which itself evokes the orality of Creole. It is the familiarity of the Creole sounds that enables the children to open up to French.

In other words, the narrator encounters another culture and language and initially feels comfortable with their unfamiliarity. It is only when the language is transferred into the classroom situation, where all the loaded associations with French and metropolitan France enter the scene, where those who can only speak Creole are ridiculed, that the tensions arise. This extract therefore raises several interesting issues. For Chamoiseau, movement between French and Creole is initially exciting, the sound of French appeals to him and he is keen to imitate those sounds and words. However, in the hierarchical school system where the languages become embedded in value systems, the movement between the two is shrouded in feelings of loss, confusion and failure. In a later essay, entitled Ecrire en pays dominé (1997), Chamoiseau has intellectualized his response to both languages, and the following quotation reveals to what extent he considers Creole to be dominated by French and the importance of resisting such oppression:

Ecrire en langue créole - Ecrire ouvert en toute langue - convie à une plongée dans le vivant du monde. [...] En devinant cette chaos-poésie des hommes peuples-mondes-reliés (déjà rodeuse en elle), la langue créole tiendra l'axe des vitalités, des émotions, des audaces esthétiques. [...] Elle neutralisera l'insidieuse dévaleur qui la mine et invalide (comme pour toute langue aujourd'hui dominée) les résistances habituelles élevées autour d'elle. (Chamoiseau 1997: 262)

Thus, for Chamoiseau, writing in Creole represents fighting on behalf of all minority languages that are under threat. Yet somewhat paradoxically, while Creole continues to be the language of intimacy and spontaneity (fictionalized in the young male narrator of the earlier autobiographical novels), the entire extract above is written in French. This appears to contradict Chamoiseau's views of writing in Creole as an act of defiance, and suggests 
that the boundary between the two languages cannot be as easily defined as he would have us believe here. In Creole, he sees a way to escape from the harsh reality of the Western world as he delves into its freedom. Yet French has given him the tools of expression with which to write, which is also a form of liberty. In the next section some of these tensions and divisions will be further explored.

\section{The difficulty of moving between languages}

The previous sub-section has demonstrated the complex associations of both Creole and French in the French Caribbean, which are deeply embedded in the colonial system. The transition between the two languages cannot be defined simply as a process whereby one moves distinctly from one to another. Could it be that the term 'translation' is itself inadequate to describe what is happening, for where does one position the source and the target language? Indeed, it is problematic to consider French and Creole to be separate, distinct languages far removed from one another when the two languages are constantly in such close contact. The cross-over point, the 'inbetween' space where they meet is also where orality and writing meet, and thus where the past meets the present. Chamoiseau has recognized the importance of this space by assigning a central role to a figure he names the Marqueur de paroles (translated in English as the 'wordscratcher'). This figure appears in his more recent works such as Texaco (1992) and notably Biblique des derniers gestes (2002), and allows the author to comfortably mediate the cross-over point as the Marqueur de paroles becomes a pivot for the multiple aspects involved in moving between a French and a Creole world. Michael Cronin (2000: 19) has proposed the image of the translator as traveller, since he straddles the 'space' in between two cultures, and in a sense, this image accurately portrays the Marqueur de paroles as well, for there is the suggestion of fluidity, emphasizing the smooth, continual flow of movement. However, there is also a sense of evasion, a refusal of ownership as if the translator/Marqueur de paroles is unable to fully immerse him/herself in either language.

Dominque Chancé (2000: 107-133) has also drawn the comparison between the role of the Marqueur de paroles and that of the translator. She demonstrates how their presence allows the acknowledgement of two elements, whether French or Creole, written or spoken word or past or present. Indeed, the Marqueur de paroles often interrupts the narrative to speak directly to the reader, a reminder that whatever s/he reads has been informed by external sources whose presence always haunt the narrative as a whole. This allows Chamoiseau to depict his own sociolinguistic reality in his fiction, while fulfilling his literary and political aim of inserting the orality of Creole into written French. The following examples of translation in one of his childhood novels show us how both languages can indeed be represented: 
Mais manman, pourquoi es-tu montée à pied? Eti man té ké pwan lajan pou trapé loto-a? Où aurais-je pris l'argent pour payer la voiture? Dit-elle. (Chamoiseau, Antan d'enfance: 23)

Joy bel kay!...sacrée maison. (44)

Ti-anmay soti en zèb mwen, petite marmaille, sortez de mes pieds. (78)

Pété fwa yo! Démolissez-les.(78)

Although the italics draw attention to the Creole, the fluid juxtaposition of the two languages creates an overall sensation of cohesion and gives more depth to the text. Even a few examples reveal how within the novel, a certain parity of status is created that transcends the sociolinguistic reality 'out there' as both languages interweave with one another and work together to convey a meaning to the (non-creolophone) reader. ${ }^{5}$

The translations are woven into the narrative as a whole which reveals the ease with which the author moves between languages, but they also construct a visibly different type of creation. In the following example from Texaco, Chamoiseau provides a subtle insight into the physical and metaphorical sensations of the tensions between the languages. The novel tells the story of Marie-Sophie and her struggles with the authorities in her quest to keep the quartier of Texaco standing, interwoven with the story of her past and her ancestors. These fragments of histoires interlink to form an overall histoire of the French Caribbean. At this point in the novel, her father Esternome is recounting the days preceding the official Abolition when he was caught between the plantation and En-ville, slavery and liberty, unsure of what either mean. As a result, he sees liberty as this elusive, intangible object, which is confused with his absent love, Ninon:

[Q]u'il s'arrêtait souvent [...] pour hurler Oh tchoué mwen ba mwen libèté mwen, Tchoué mwen mé ba mwen Ninon mwen an, Oh tuez-moi mais laissezmoi la liberté, tuez-moi mais laissez-moi Ninon!...et il fut toujours pas très possible de distinguer de quelle-auquelle des deux il s'inquiétait vraiment. (Chamoiseau, Texaco: 98) (emphasis added)

The verb 'hurler' reveals the confusion and sense of oppression that threaten to destroy Esternome, haunting him at all moments in his desperate desire for liberty and for Ninon. They have both become indistinguishable from each other, mainly because he does not know what liberty is and what it means ('Mais être “libre” c'est quoi-est-ce?' (Texaco: 81)). The languages of French and Creole combine to intensify both the strength but also the tumult of his feelings - the Creole moves seamlessly into the French allowing each to stand out as two separate languages without opposition. The narrator is providing the reader with a translation of the Creole, but the blurring and confusion of Esternome's feelings seems to be symbolized in the physical indistinction of the two languages as they appear on the page of the 
novel. I would suggest that this one example is a metaphor for the tensions and pain of the Self that is torn or split, and how language can soften such tensions. For the source of Esternome's angst is the desperately awaited liberty. The desire for the freedom from slavery is here asserted through a combination of Creole and French, which unite to make the liberation of those thoughts possible.

For Chancé, this creation of a plural opaque 'language' seen in Chamoiseau's work that goes beyond translation also occurs in the writings of fellow Martinican author and essayist, Edouard Glissant, 'C'est en analysant dans le détail le jeu du créolisme, de la traduction du créole au français ou de la transcription de l'un à l'autre que nous pourrons concevoir ce que [Glissant et Chamoiseau] appellent 'langage', et qui est, pour eux, transcendant aux langues" (Chancé 2000: 121). This parallel drawn between the two Martinican authors suggests that the open-ended, plural language they are creating is emerging from their local environment and linguistic experiences. Here we are undoubtedly in the realms of Khatibi's definitions of the bilingue-bilangue, outlined by Samia Mehrez (1992). She describes how the former is a clear-cut separation between 'languages', whereas the latter is a more slippery movement between the two, involving several layers of language that are continually shifting. Indeed, by looking at some of the ways in which Chamoiseau inserts Creole into the written French, it becomes clear that it is often difficult to pinpoint at which point one language ends and another begins: a creative process is thus taking place.

[N]ul n'a jamais disposé devant le negrillon d'un assez de mémoire pour en évoquer quelques temps de splendeur. (Chamoiseau, Antan d'enfance: 41) (emphasis added)

Il pénétra dans la maison avec l'air de ne pas trop en croire les cocos de ses yeux. (43) (emphasis added)

Despite the marginality of the Creole, its presence alters the visual appearance and sound of the French quite dramatically. The startling image of 'cocos' (i.e. coconuts) to describe protuberant eyes is culture-specific and alien to the Metropolitan French environment. The text's langage is neither completely French, nor completely Creole yet is still comprehensive to speakers of either language. A constant process of 'translation' is, in fact, materializing on the page, and one that is far from reductive; it does not dilute either language: and thus a form of translation is still occurring. Above all, descriptions such as this one reinforce the sense of linguistic movement within Chamoiseau's work.

In fact, this plural and fluctuating movement of languages seems to render the term 'translation' obsolete, for it does not accurately describe the movement occurring in Chamoiseau's texts. It is often unclear where one language begins and another ends. The specificity of the Martinican sociolinguistic situation and opaque flux of language movement in Chamoiseau's writing renders the concept of 'translation' highly problematic; 
Bebel-Gisler, the Guadeloupean linguist describes the dilemma in succinct terms: "[I]l devient clair que le problème n'est pas tant de traduire le créole en français, mais de se traduire, nous traduire, nous dire, nous exprimer" (1989: 30). Within the French Caribbean context, Bebel-Gisler repositions the entire question of translation, turning it from a movement between languages, into a movement between self-expression and language. The examples explored below point to the insightfulness of Bebel-Gisler's observation. Due to the specificity of the formation of the Creole language on the plantations and its irrevocable link with violence and injustice, the power struggles that surround the relationship between French and Creole cannot be considered as simply a linguistic dilemma. In addition, in contemporary French Caribbean society, both languages are needed to express their everyday reality. Moreover, the movement between French and Creole takes place within one person. The languages therefore merge within one space, thereby creating a form of what Glissant would call 'créolisation'. ${ }^{6}$ In fact, the 'hybrid' forms of the two languages are often referred to, somewhat pejoratively, as français banane, le créole francisé or le français créolisé. These terms are obviously inadequate to fully describe the processes that are taking place. Indeed, these terms suggest that a loss occurs, as if both the French and the Creole are somehow crippled by their interaction. What is suggested here instead is that the newly created language form is not a bastardized hybrid, not an entity that is not quite complete, but an entirely new form of expression, a new language form that cannot be anything other than plural, kaleidoscopic and fluid because of the continual movement of the different elements that constitute it. It is this linguistic creation that allows the author in the form of the Marqueur de paroles to construct what Glissant terms his langage, which is constructed in the very space where speaking and writing meet.

This langage can be seen as the 'end product' of the several layers of 'translation' occurring in the text as the narrator attempts to put into written form the oral versions (that have already been told and retold), and dire the words of his interlocutors. This relationship transcends the binary poles of opposition between Creole and French that were moulded and rigidified by the colonial process, but also avoids a straightforward reversal of their roles. There is no linear movement between languages, rather, this new form of interaction at times has the force of a violent assault. The sense of this violence is constructed through the continual repetition of the power of the parole (and all its unequivocal associations with Creole and orality) as a weapon. A significant example can be found in Esternome's description of the difference between the béké meaning of the word 'l'esclavage', and the slaves' understanding of it:

Pour nous, c'était entendre: l'estravaille. Quand ils le surent et le dirent à leur tour Lestravaille pour nous parler en proximité, nous avions déjà raccourci l'affaire sur l'idée du travail...hi hi hi, la parole sillonnait Sophie, la parole sillonnait comme une arme. (Chamoiseau, Texaco: 58 ) 
The 'translation' of the word 'esclavage' appears to be impossible because of the loaded associations of the word. The word has evolved physically and also in meaning, where it will always be connected with the brutal misery of the plantation fields. The violence is thus contained in the unforgotten memories of the horror of slavery, and its inseparable link with the Creole language. The narrator does not allow us to forget this link in the symbolic use of the word 'sillonner', evoking the shape and form of the soil on the plantations. Indeed, the image created by this one example of the movement from Creole to French could be conveyed by the word 'sillonner', which suggests that the processes that are occurring in the French Caribbean are not straightforward (neither horizontal nor vertical) but that their contours are curved and difficult to trace, following different patterns. Yet this interaction is not always charged with violence, and at times can be sensual and flirtatious. This is most notable in the oral interjections of Creole that dot the entire narrative and serve to jig it along, creating a rhythm that is not French, such as "coco de ses z'yeux" (Chamoiseau, Texaco: 62), "cette parolaille" (72), "La salle se vida floup!" (85), and the repetition throughout of sounds such as 'isalop', 'tchoup', which again draw attention to the power of the spoken word (i.e. Creole), as does "comme l' abeille bourdonne vers l'en-fondoc des fleurs" (116). Here we have a non-Antillean image of a buzzing bee whose movement is then described using Creole onomatopoeia, both languages combining to create a new image that is understandable to all.

Above all, it is a form of poetic discourse, which resists any rigidity and appears to transcend the sociolinguistic dilemma of the French Caribbean. This is therefore not a case of translation, but an expression of a new form where the focus is on the space in-between the two languages, and the two worlds which constitute everyday reality in the French Caribbean. The fluidity of such an exchange is the means through which the Creole language can negotiate its own power, freed from the need to set up dichotomies, or centres and peripheries. Both languages have been momentarily liberated from the restraints put into place by fixed roles and boundaries. Such a liberation can occur in the body of a narrative when the two languages interweave with one another, but neither is undermined in the process.

\section{Into chaos and resistance}

The movement 'between' French and Creole in Chamoiseau's work has hereby been explored, as well as the ways in which a fusion of the two languages leads to the creation of a new one. A langage that transcends translation, that may even render the term redundant. This raises the question: what term could describe this movement between languages instead? For Glissant, the difficulty of deciphering a language completely is a positive necessity. This is illustrated in his statement, "Tu me parles dans ta langue, et c'est dans 
la mienne que je te comprends" (Glissant, 1990: 122). The linguistic movement that takes place between two individuals, works in opposite directions, which Glissant views as the principle of his 'chaos-monde'. It is perhaps inevitable that there should be a fissure in communication between individuals, a slight gap between what is said and what is understood that goes beyond language itself. This small allowance for chaos foregrounds difference and individuality. Glissant contrasts this with the monolingualism of the Western world and its move towards globalization: “[...] c'est à dire non pas le refus de l'autre, mais le refus de considérer l'autre comme une transparence, et par conséquent, la volonté d'accepter l'opacité de l'autre comme une donnée positive et non pas comme un obstacle" (1994: 127). ${ }^{7}$ Therefore opacity, and the resistance to complete submission to another language, render translation impossible. The 'chaos-poésie' advocated by Chamoiseau instead (cf. above), allows for differences to exist side by side. Amidst the power struggles of the French Caribbean, where language choice is surrounded by ambiguity and torn loyalties, resistance to transparency (and therefore to translation) provides a very particular opening for the future. It holds possible solutions for some of the sociolinguistic tensions that have been explored in this article.

Indeed, in his latest novel Biblique des derniers gestes $(2002),{ }^{8}$ Chamoiseau appears to have liberated himself from the struggle between French and Creole. It appears that he has adapted Glissant's theories, demonstrated in the opacity of the language and the chaotic movement of the narrative. His writing appears to tackle issues that go beyond those facing his local communities in Martinique and is instead directed against universal hatred and violence. His general disillusionment with an increasingly urban society, with no interest in its past, nor in writing, is symbolized in the central protagonist Bodule-Jules's rescue of his niece Caroline from a terrifyingly empty and hostile environment that represents the underworld of drugs and violence. There is no place for the old battles of colonized against colonizers, or Creole versus French in this context. Everyone has become numbed by a general anaesthesia composed of drugs, television and the new imperialism of globalization.

Now that Chamoiseau is less interested in asserting the Creole language in the political manner that was so prominent in his earlier novels (Chronique des sept misères (1986), Solibo Magnifique (1988)), Creole has become representative of a wider, and more important struggle. Indeed the linguistic struggle is almost completely absent from the entire narrative in Biblique des derniers gestes (2002) and instead 'haunts' the novel's language, as is seen in the following example where Bodule-Jules meets a fantastical half-female/half-male character whose ever-fluid identity seems to symbolize the language movement between Creole and French:

Il [Polo Carcel] apprit à effacer en lui cette partition qui divisait l'humanité. Sous la voix du monsieur qu'il cultivait chaque jour, il sentit emerger une 
voix de petite fille, puis un timbre de madame. Ces deux voix purent se parler, échanger leurs façons et leurs visions des choses. Polo Carcel fut à jamais deux personnes au même temps. Un couple parfait logé dans une même chair. (Chamoiseau, Biblique des derniers gestes: 66)

Such a harmonious vision of coming to terms with difference, and accepting the multifarious dimensions of one's identity could be seen to highlight Chamoiseau's optimism for the future. Verbs like 'cultivait' and 'apprit' emphasize the degree of effort required to reach this harmony. It can hardly be a coincidence that the physical embodiment of such tolerance is conveyed to the reader through a character who transcends definable borders. Chamoiseau thereby suggests through his literature that it is possible for an individual to be inhabited by several languages and to communicate and move between all of them. Moreover, Polo's profession as a dancer symbolizes the fluidity of the movement, and his physical prowess ( $\mathrm{s} / \mathrm{he}$ teaches Bodule-Jules how to fight) asserts a strong, visible presence on the page.

In other words, the opacity and refusal to aid the reader in Biblique des derniers gestes, can be seen in Glissantian terms. The author is creating a langage that asserts difference as a kind of poetics, an example of créolité that is presented as an example for the rest of the world to follow:

Accepter les différences, c'est bien sûr bouleverser la hiérarchie du barème. Je 'comprends' ta différence, c'est-à-dire que je la mets en rapport, sans hiérarchiser, avec ma norme. Je t'admets à existence, dans mon systeme. Je te crée une nouvelle fois. - Mais peut-être nous faut-il en finir avec l'idée même du barème. Commuer toute réduction. (Glissant, 1990: 204)

Accepting difference means accepting opacity and the inability to fully comprehend the other. From this perspective the power struggles that exist in the French Caribbean can be suspended, at least on an abstract level. In Chamoiseau's latest novel, the author has attempted to remove himself from these struggles by forming his own 'système' through language.

\section{Conclusion}

In the above exploration of language movement, the study of one contemporary author has allowed us to trace some of the changes in the movements in literature between French and Creole in Martinique and thus reveal the problems of the term (and even concept) of 'translation' in the French Caribbean. The islands' passage from colony to Département d'Outre-Mer has created a sociolinguistuic situation in which the straightforward diglossia of the past has slowly been eroded yet the tensions and loyalties that surround both Creole and French remain unresolved. The autobiographical novels of Chamoiseau's childhood represent such tensions, and translate for the reader the confusion and difficulty in which, for him, French is embedded. In an attempt to resolve these tensions, Chamoiseau creates the figure of the 
Marqueur de paroles who forces the reader to confront the orality of Creole, and of the past. As an 'in-between' figure who mediates between languages, as well as the past and present, the Marqueur de paroles is continually moving between the tensions that constitute Chamoiseau's literary and linguistic reality. However, as we delve further into this movement, it becomes clear that even the written French narratives are inhabited by Creole sounds and words. The 'translation' has occurred before the words are written and due to the fluctuating movement it involves, the term no longer accurately describes what is occurring between the languages. This new creation has moved beyond translation and has actually moved into chaos as outlined by Glissant. This form of chaos is positive because it allows for constant movement in all directions, thereby removing any form of hierarchy. Its very opacity gives Chamoiseau the freedom to incorporate and express all the elements that represent his reality. It remains to be seen whether this new langage that is the result of his movement into chaos will grant him the freedom he craves from the oppression of the past.

\section{Bibliography}

\section{Primary texts}

Chamoiseau, Patrick (1986). Chronique des sept misères. Paris: Editions Gallimard. Chamoiseau, Patrick (1988). Solibo Magnifique. Paris: Editions Gallimard.

Chamoiseau, Patrick (1992). Texaco. Paris: Editions Gallimard.

Chamoiseau, Patrick (1993). Antan d'enfance. Paris: Editions Gallimard.

Chamoiseau, Patrick (1994). Une enfance créole II: Chemin d'école. Paris: Editions Gallimard.

Chamoiseau, Patrick (1997). Ecrire en pays dominé. Paris: Editions Gallimard.

Chamoiseau, Patrick (2002). Biblique des derniers gestes. Paris: Editions Gallimard.

\section{Secondary texts}

Bassnett, Susan \& Harish Trivedi (eds) (1999). Post-Colonial Translation: Theory and Practice. London/ New York: Routledge.

Bernabé, Jean, Patrick Chamoiseau \& Raphaël Confiant (1989). Eloge de la créolité. Paris: Editions Gallimard.

Bebel-Gisler, Dany (1989). Le Défi culturel guadaloupéen. Paris: Editions Caribéennnes.

Chancé, Dominque (2000). L'Auteur en souffrance. Paris: Presses Universitaires de France.

Cronin, Michael (2000). Across the Lines: Travel, Language, Translation. Cork: Cork University Press.

Gentzler, Edwin (2001). Contemporary Translation Theories. Revised $2^{\text {nd }}$ Edition. Clevedon: Multilingual Matters.

Glissant, Edouard (1981). Le Discours antillais. Paris: Editions du Seuil.

Glissant, Edouard (1990). Poétique de la relation. Paris: Editions Gallimard.

Glissant, Edouard (1994). "Le Chaos-monde, l'oral et l'écrit.” R. Ludwig (ed.) (1994). Ecrire la "parole de nuit": La Nouvelle littérature antillaise. Paris: Folio, 111-129. 
Kremnitz, Georg (1983). Français et créole: ce qu'en pensent les eneignants - le conflit linguistique de la Martinique. Hamburg: Verlag.

Ludwig, Ralph (ed.) (1994). Ecrire la "parole de nuit": La Nouvelle littérature antillaise. Paris: Folio.

Mehrez, Samia (1992). "Translation and the Postcolonial Experience: The North African Text." L. Venuti (ed.) (1992). Rethinking Translation - Discourse, Subjectivity, Ideology. London/New York: Routledge, 120-138.

March, Christian (1996) Le Discours des mères martiniquaises - diglossie et créolité: un point de vue sociolinguistique. Paris: L'Harmattan.

Simon, Sherry (1992). "The Language of Cultural Difference: Figures of Alterity in Canadian Translation." L. Venuti (ed.) (1992). Rethinking Translation Discourse, Subjectivity, Ideology. London/New York: Routledge, 159-176.

Simon, Sherry (1999). "Translating and Interlingual Creation in the Contact Zone Border Writing in Quebec.” S. Bassnett \& H.Trivedi (eds) (1999). Post-colonial Translation: Theory and Practice. Translation Studies. London/New York, 58-74.

Suk, Jeannie, (2001). Postcolonial Paradoxes in French Caribbean Writing Césaire, Glissant, Condé. Oxford: Clarendon Press.

Venuti, Lawrence (ed.) (1992). Rethinking Translation - Discourse, Subjectivity, Ideology. London/New York: Routledge.

${ }^{1}$ Such as those by Bassnett \& Trivedi (1999) and in Venuti (1992).

${ }^{2}$ For further details of the recent sociolinguistic situation in Martinique, see Kremnitz (1983), Bebel-Gisler (1989) and March (1996).

${ }^{3}$ As most of the indigenous Amerindians had been destroyed by the colonizers, there were very few native speakers remaining. The African slaves had been deliberately separated from their tribes by the colonizers to ensure that they could not communicate with each other and to lessen the risk of mutiny on the journey across to the Caribbean. This linguistic diversity was further compounded by the fact that Standard French did not yet exist at the time and this therefore meant that the colonizers, speaking their native dialects (mainly Norman, Breton and Ile de France), would also have had problems communicating with one another.

${ }^{4}$ Patrick Chamoiseau has written a number of novels since the 1980 s, one of which Texaco (1992) won the Prix Goncourt. He is also a founding member of the literary and political movement créolité, which attempts to promote a global Creole identity that allows each individual to embrace their multiple origins and also to confront the plurality of their past by embracing multilingualism.

${ }^{5}$ Although Chamoiseau's work is popular in France where he has won several prestigious literary prizes (e.g. the Prix Goncourt 1992), in his native Martinique it is mainly the intellectuals who read his work.

${ }^{6}$ In Discours antillais (1981) and Poétique de la relation (1990), Glissant views what is happening in the Caribbean as a whole as a process of creolization in which the multiple strands of the population's collective past are interwoven to create a plural, fluctuating identity.

${ }^{7}$ Glissant's essay is analyzed in greater detail by Dominque Chancé (2000: 124-127) in the chapter entitled "Ecrire/traduire la parole: Inventer une langue" where she highlights Glissant's emphasis on the impossibility of translation as something that is reductive and therefore counters his belief in the importance of asserting the difference in each language.

${ }^{8}$ The novel is composed of two parallel histories, firstly the epic adventure of the central character Bodule-Jules' life, and secondly a potted history of Antillean so- 
ciety until the present day. Throughout the course of the novel, these two central stories echo/reflect one another and the reader is thus bombarded with a series of fragmented histoires that are positioned in a broad chronological framework. 